\title{
THE FUNCTION OF THE HEART-BODY IN POLYCHAETES
}

\author{
By G. Y. KeNNEDY \\ Cancer Research Unit, University of Sheffield, \\ and R. Phillips Dales \\ Department of Zoology, Bedford College, London
}

(Text-figs. I-9)

Loose, spongy intravasal tissues are common in polychaetes. In some this tissue is localized and forms a discrete plug or strand known as the heartbody. Such structures occur in the anterior part of the dorsal vessel in terebellids, ampharetids, cirratulids, amphictenids and flabelligerids.

Many authors have described the heart-body in different species and speculated about its function. Picton (1898) examined in some detail the heart-body in the cirratulid Audouinia tentaculata and in the terebellids Polymnia nebulosa and Terebella meckelii. He concluded that in Polymnia at least, the heart-body is formed by infolding from the epithelium on the outside of the vessel, so that it is comparable with the chloragogen cells which, in many polychaetes, clothe the outside of the vessels. Salensky (I884) working on Terebella, came to the same conclusion. Eisig (I887) also pointed out that such extravasal chloragogen cells are absent in species with intravasal heart-bodies, and compares the chloragosomes or yellow-green granules found in the chloragogen cells with the granules found in the heart-body. Romieu (I923) comes to similar conclusions. Fauvel (I897) concluded from his study of the ampharetids, that the heart-body served a valvular function, and suggested that it also removed and stored substances extracted from the blood, but was not directly related to the amoebocytes. Schneider (I897, I899), on the other hand, concluded that the organ was related to the phagocytic and excretory systems in the amphictenid, Pectinaria. Picton (1898) concluded that the greenish granules were removed from the heart-body to the coelomic fluid, and from there to the outside by the nephridia, since the quantity of pigment did not appear to be greater in older worms.

In addition to the greenish or yellow granules in the heart-body, Picton (I898) also found fat, iron, and brownish 'chitinous bodies'. Iron was also detected by Bloch-Raphael (I939) and Romieu (I923), and its occurrence suggests an haematopoietic function. Schneider (1897), who also found iron in the heart-body of Pectinaria, claimed that this increased after injection of 
iron saccharate into the coelom; Meyer (1887) also suggested, from his study of the cirratulid Chaetozone, that the heart-body is an haematopoietic organ.

The histological structure of the heart-body does not differ greatly in polychaetes belonging to different families, although it is variable in size and extent within the dorsal vessel, and may also increase with age (Ashworth, 1904). It is perhaps most extensive in the cirratulids, but seems best developed in the terebellids. The appearance of the heart-body of Audouinia tentaculata in transverse section is shown in Fig. I. The organ in cirratulids extends throughout the region in which the dorsal vessel supplies vessels to the

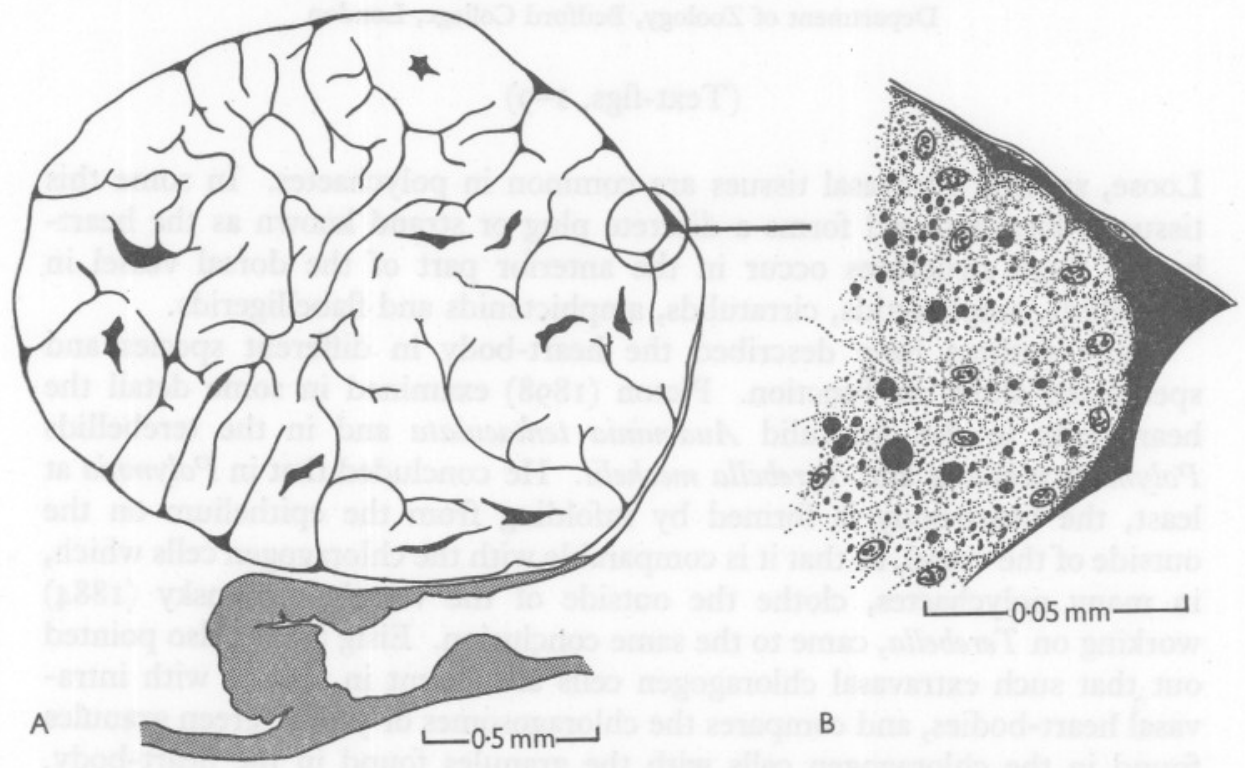

Fig. I. Audouinia tentaculata, heart-body; A, section of whole organ, with gut-wall shaded; B, enlarged detail of part of A.

branchiae, and the general occurrence of heart-bodies in those polychaetes with specialized gill structures suggests that the organ has a mechanical function, as Picton (1898) concluded; certainly at systole the lumen of the dorsal vessel is completely obliterated by the wall of the vessel contracting on to the heart-body. It is perhaps not unreasonable to suppose that such loosely compacted tissue may have acquired other functions; a physiological parallel may be found in the vertebrate bone-marrow.

In the present work, pigment analyses have been made of the heart-bodies from the following species representing the main families of polychaetes in which discrete heart-bodies are found: Amphitrite johnstoni Malmgren, Terebella lapidaria L., Lanice conchilega (Pallas) (Terebellidae); Audouinia tentaculata (Montagu), Cirratulus cirratus (O. F. Müller) (Cirratulidae); 
Melinna palmata (Grube) (Ampharetidae); and Flabelligera affinis Sars (Flabelligeridae). Unfortunately, insufficient specimens of Pectinaria were collected to make pigment examination of the heart-body possible. The heart-bodies of Amphitrite johnstoni and Audouinia tentaculata have also been examined histologically and histochemically. Similar chemical methods have been applied to other tissues in all these worms for comparison, and the work extended to Polycirrus caliendrum Clap. (Terebellidae), Myxicola infundibulum (Renier) (Sabellidae) and Arenicola marina L., none of which has a discrete heart-body, although there is a little intravasal tissue in the latter genera; Polycirrus has no vascular system. The extravasal tissue present in old Arenicola has also been examined histologically (Fig. 2), histochemically, and subjected to the same procedures to be described for Amphitrite.

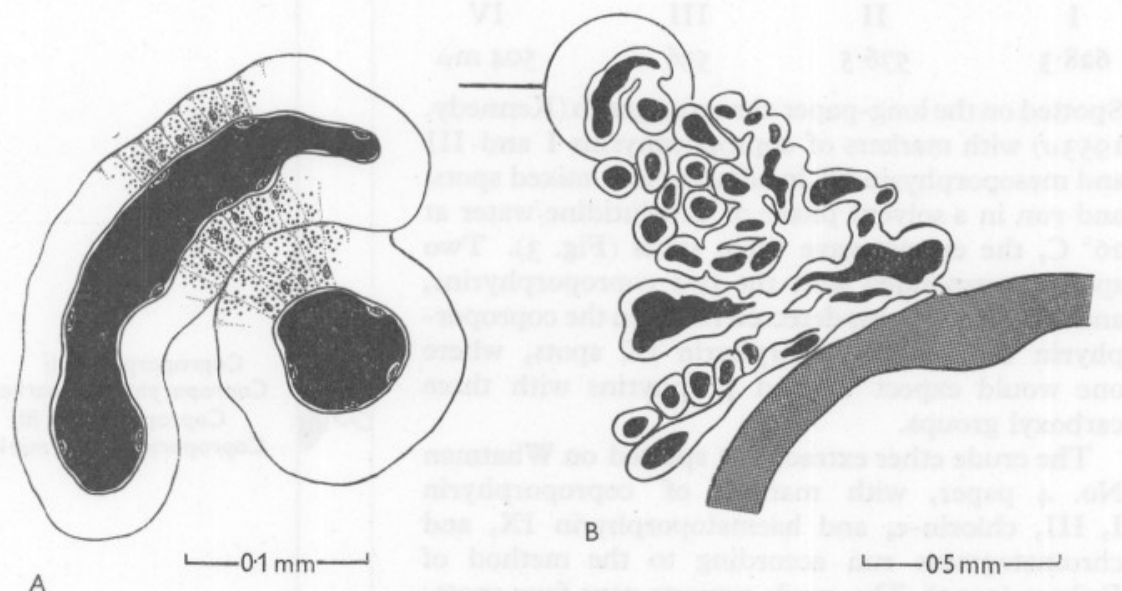

Fig. 2. Arenicola marina, extravasal tissue; A, detail of part of tissue; B, section of tissue, with gut wall shown shaded.

The work described in this paper was done at the Plymouth Laboratory, and we would like to express our appreciation of the facilities and help afforded to us by the Director and Staff, in particular Mr F. A. J. Armstrong for copper analysis; to Miss M. L. Weir for preparing the sections represented in Fig. 2, and to $\mathrm{Mr}$ A. C. Briggs for collecting material. We are also grateful to $\mathrm{MrW}$. H. Lockwood, of the Department of Chemical Pathology, University College Hospital Medical School, London, for some helpful discussion.

\section{METHODS}

The tissues from the animals examined were extracted by the methods described by Kennedy \& Vevers (1953, 1954). Whenever possible, the pigments detected were isolated, melting points determined, and some 
characteristic derivatives prepared. Absorption spectra were determined in the Beck-Hartridge Reversion Spectroscope, in the Unicam S.P. 500 Spectrophotometer, and in the Beck microspectroscope.

\section{RESULTS}

The main results are presented in Table $\mathrm{I}$.

Heart-body

Amphitrite johnstoni

Ether-acetic acid extracts from fifteen heart-bodies were washed with water containing some potassium acetate. The hypophase was bright yellow and showed a fine green fluorescence in u.v. light. The epiphase was red-fluorescent in u.v. light, and gave a spectrum (Hartridge):

$\begin{array}{cccc}\text { I } & \text { II } & \text { III } & \text { IV } \\ 628 \cdot 3 & 576 \cdot 5 & 536 & 504 \mathrm{~m}_{\mu}\end{array}$

Spotted on the long-paper chromatograph (Kennedy, I953a) with markers of coproporphyrins I and III and mesoporphyrin IX in adjacent and mixed spots, and run in a solvent phase of 2:6-lutidine/water at $26^{\circ} \mathrm{C}$, the extract gave three spots (Fig. 3). Two spots corresponded with the two coproporphyrins, and another spot was detected between the coproporphyrin III and mesoporphyrin IX spots, where one would expect to find porphyrins with three carboxyl groups.

The crude ether extract was spotted on Whatman No. 4 paper, with markers of coproporphyrin I, III, chlorin- $\mathrm{e}_{6}$ and haematoporphyrin IX, and chromatograms run according to the method of Eriksen (1953). The crude extracts gave four spots: two corresponded with those given by coproporphyrins I and III, there was one spot at the tricarboxylic level (see below, Band 3), and one dark-coloured non-fluorescent spot joining the latter with that given by coproporphyrin III (Fig. 4). This dark spot is probably a haematin.

Extracts of a further fifteen heart-bodies in methanol-sulphuric acid were diluted with an equal volume of water and extracted with chloroform. The chloroform extract was washed with $2 \%$ sodium chloride, and then with water, and concentrated in vacuo. This solution gave a spectrum (Hartridge):

$\begin{array}{cccc}\text { I } & \text { II } & \text { III } & \text { IV } \\ 626.3 & 573.5 & 540 & 506.2 \mathrm{~m} \mu\end{array}$

After a further washing, the esterified pigment was spotted on Whatman No. I C.R.L. slotted paper, and chromatograms run according to the method of

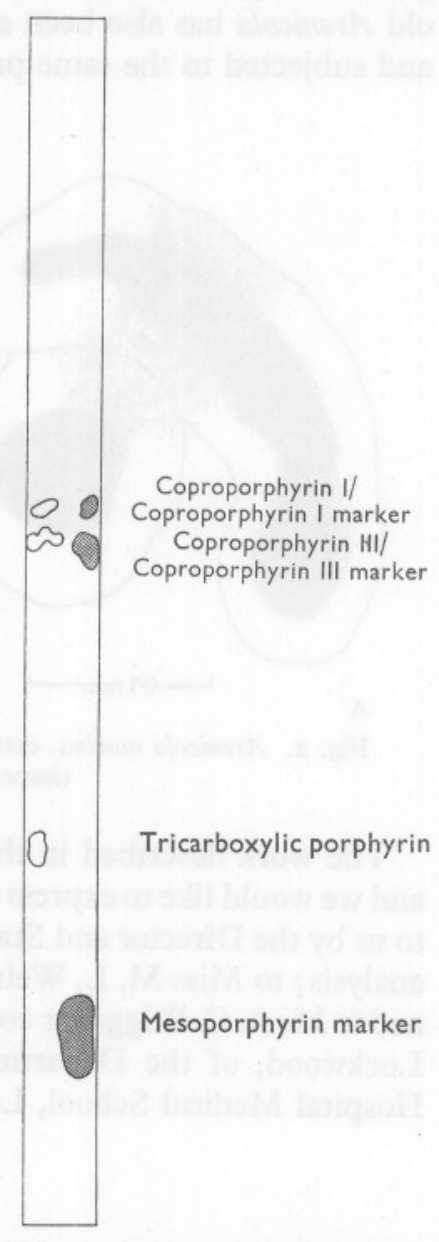

Fig. 3. Long-paper descending chromatogram of extract of Amphitrite heart-body, with adjacent markers. 
Chu, Green \& Chu (I95I) for separating isomers of the coproporphyrins. Coproporphyrins I and III esters, and mesoporphyrin IX ester were used as markers. By this method, both the isomers I and III of coproporphyrin were found in the extract (Fig. 5). The chloroform solution of the pigment esters was then chromatographed on a column of magnesium oxide grade III (Nicholas, I95I) packed in chloroform. The chromatogram was developed with methanol-in-chloroform, $0.5, \mathrm{I}$ and $2 \%$, successively, and the fractions collected separately as the bands were eluted. Four fractions were obtained as follows:

Band I. Brownish red fraction passing quickly down the column and out. Redfluorescent in u.v. light. Hartridge spectrum:

$\begin{array}{cccc}\text { I } & \text { II } & \text { III } & \text { IV } \\ 645 & 586 & 545 & 504 \mathrm{~m} \mu \text { (Chlorin-type) }\end{array}$

TABLE 1. LOCALIZATION OF THE PIGMENTS IN THE TISSUES

Yellow green- Blue-

Amphitrite

Heart-body

Coelomic cells

(pink)

Coelomic cells

(brown)

Blood

Body wall

Gut

Terebella

Heart-body

Coelomic cells

Blood

Body wall

Gut

Lanice

Heart-body

Gut

Cirratulus

Heart-body

Body wall + gut

Audouinia

Heart-body

Blood

Body wall

Gut

Melinna

Heart-body

Body wall

Gut

Flabelligera

Heart-body

Body wall

Gut

Polycirrus

Whole body

Body wall

Gut

Myxicola

Anterior nephridia

Body wall + gut

Arenicola

Extravasal tissue

Body wall (dark)

Body wall (pink)

Uro I Copro I Copro III 3-COOH Proto IX Haematin fluorescent fluorescent

\begin{tabular}{|c|c|c|c|c|c|c|c|}
\hline - & $\stackrel{+}{-}$ & $\begin{array}{l}+ \\
+\end{array}$ & \pm & - & + & \pm & - \\
\hline - & - & + & - & - & + & - & - \\
\hline - & - & - & - & - & $+(\mathrm{Hb})$ & - & - \\
\hline - & $\overline{-}$ & \pm & $\overline{-}$ & $\overline{-}$ & \pm & \pm & $\overline{-}$ \\
\hline & - & - & - & & & & - \\
\hline - & - & + & - & - & - & - & - \\
\hline & - & - & - & - & + & - & - \\
\hline - & $\bar{z}$ & $\overline{-}$ & $\overline{-}$ & $\overline{-}$ & $\pm(\mathrm{Hb})$ & $\overline{-}$ & $\overline{-}$ \\
\hline- & - & $\overline{-}$ & $\overline{-}$ & $\overline{-}$ & $\overline{-}$ & - & - \\
\hline - & - & + & - & - & - & - & - \\
\hline - & - & + & - & - & - & - & - \\
\hline - & - & + & - & - & + & - & - \\
\hline - & - & - & - & - & + & - & - \\
\hline - & + & + & - & - & - & - & + \\
\hline - & + & + & - & - & $+(\mathrm{Hb})$ & - & - \\
\hline - & $\bar{t}$ & $\bar{t}$ & $\overline{-}$ & $\overline{-}$ & $?$ & $\overline{-}$ & $\bar{t}$ \\
\hline & $T$ & & & & & & \\
\hline- & - & + & - & - & - & + & - \\
\hline- & - & - & - & $\overline{-}$ & - & - & $\overline{-}$ \\
\hline - & - & - & - & - & - & - & - \\
\hline - & - & + & - & - & - & - & + \\
\hline- & - & - & - & - & - & - & + \\
\hline - & - & + & - & - & - & - & - \\
\hline - & - & + & - & - & - & - & - \\
\hline$\pi$ & - & + & - & - & - & - & - \\
\hline - & - & + & - & - & - & - & - \\
\hline - & - & - & - & - & - & - & - \\
\hline - & - & + & - & - & + & - & - \\
\hline . & + & + & + & - & + & - & - \\
\hline - & + & + & + & $\overline{-}$ & + & $\stackrel{+}{+}$ & - \\
\hline
\end{tabular}

$(\mathrm{Hb})=$ from haemoglobin. 
In the spectrophotometer, only the band at $643 \mathrm{~m} \mu$ was detected, probably owing to impurity. This spectrum resembles that given by dioxymesoporphyrin:

$$
\begin{array}{cccl}
\text { I } & \text { II } & \text { III } & \text { IV } \\
640 & 584 & 542 & 504 \mathrm{~m} \mu \text { (chlorin type) }
\end{array}
$$

This pigment could be an artefact arising during manipulation of the pigments.

Band 2. A wide pink band, obviously the main pigment present. This was collected after elution with $0.5 \%$ methanol in chloroform. This gave a spectrum in the Unicam:

$$
\begin{array}{ccccc}
\text { I } & \text { II } & \text { III } & \text { IV } & \text { Soret } \\
622 & 569 & 535 & 501 & 405 \mathrm{~m} \mu \text { (aetio-type) }
\end{array}
$$

This is the spectrum given by coproporphyrin.

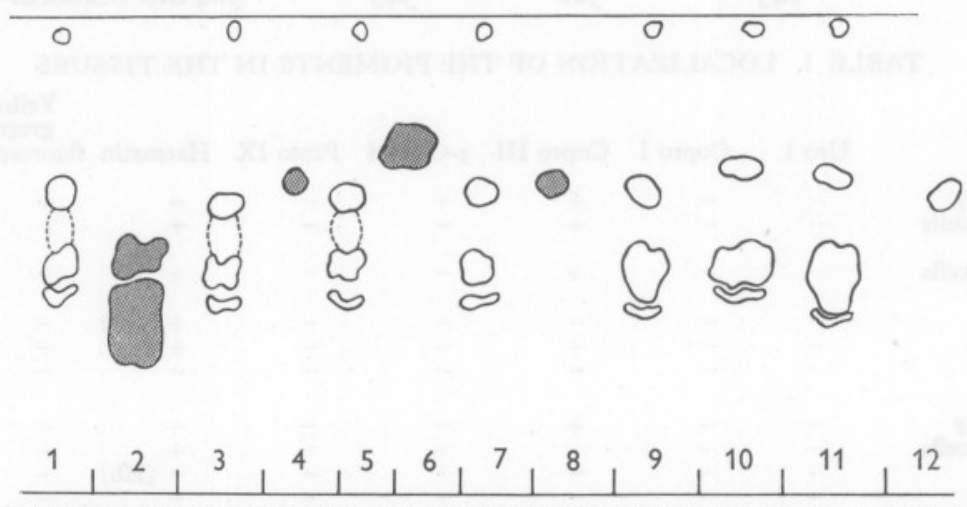

Fig. 4. Ascending paper chromatogram of Amphitrite heart-body and Arenicola tissue extracts. Solvent 2:6-lutidine/water at $26^{\circ} \mathrm{C}$ in atmosphere of $\mathrm{NH}_{3}$. The small spots at the top are carotenoids; the other spots are as follows: (I) Amphitrite heart-body; (2) coproporphyrin III (lower) and coproporphyrin I; (3) Amphitrite heart-body ; (4) chlorin- $\mathrm{e}_{6}$; (5) Amphitrite heartbody; (6) haematoporphyrin; (7) Amphitrite heart-body; (8) chlorin- $\mathrm{e}_{6}$; (9) Arenicola extravasal tissue; (IO) Arenicola body wall (light); (II) Arenicola body wall (dark); (I2) Amphitrite heart-body $3-\mathrm{COOH}$ spot.

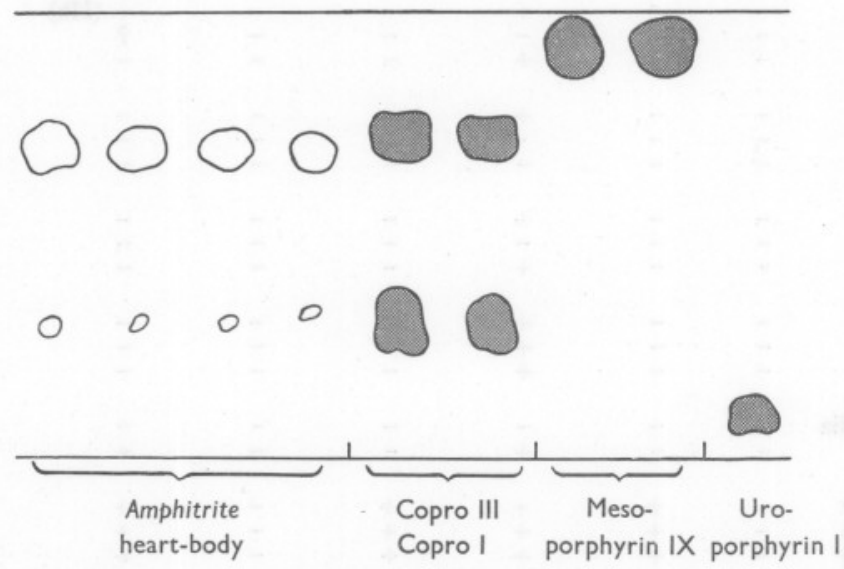

Fig. 5. Separation of porphyrin isomers by Chu, Green \& Chu technique (195I). 
Band 3. A third red-fluorescent band appeared which travelled much more slowly than the preceding band, and was eluted with $2 \%$ methanol in chloroform. This band gave a spectrum in the Unicam:

$\begin{array}{ccccc}\text { I } & \text { II } & \text { III } & \text { IV } & \text { Soret } \\ 622 & 572 & 538 & 503 & 404 \mathrm{~m} \mu \text { (aetio-type) }\end{array}$

Band 4. Some pigment remained close to the top of the column and could not be eluted even with $5 \%$ methanol in chloroform. The column was pushed out and this band cut off with a razor blade. The brown material at the very top of the column was discarded, and the red-fluorescent material eluted with chloroform containing a trace of formic acid. The chloroform extract was washed with water containing a little potassium acetate and then with water to remove the formic acid. The remaining chloroform solution gave a spectrum in the Unicam:

$$
\begin{array}{ccccc}
\text { I } & \text { II } & \text { III } & \text { IV } & \text { Soret } \\
62 \mathrm{I} & 568 & 535 & 500 & 402 \mathrm{~m} \mu \text { (aetio-type) }
\end{array}
$$

This spectrum resembles that of coproporphyrin, and it is possible that this is unesterified pigment in view of its chromatographic behaviour, although free coproporphyrin is normally somewhat insoluble in chloroform.

Band I containing the pigment which resembles dioxymesoporphyrin could be, as already mentioned, an artefact due to oxidation during the extraction process. In the first paper chromatograms carried out, no spot at the 2-carboxyl level was obtained from the crude Amphitrite heart-body extracts. However, in later chromatograms a trace of red fluorescence at the 2-carboxyl level was in fact obtained. This would lend credence to the view that this pigment is indeed an oxidation artefact.

Band 2, which contains the bulk of the porphyrin present in the heart-body, was shown, by the technique of Chu et al. (I95I), to be a mixture of coproporphyrins I and III, with the III isomer predominating (Fig. 5). The isomers were separated by the Chu et al. (I95I) method, the spots of the isomers were cut out with scissors, and those of each isomer pooled. The porphyrin esters were eluted with chloroformmethanol mixture $100: 2$, and the methanol washed out with water containing some potassium acetate to prevent the coproporphyrin from passing into the water phase. After a further washing with water, the chloroform solutions were roughly dried by filtering through chloroform-soaked filter papers, and the pigments crystallized. Coproporphyrin III was crystallized by evaporating to a volume of $3 \mathrm{ml}$. and adding an equal volume of dry ether, stirring all the time. The mixture was placed in the ice chest for some hours, when clusters of coproporphyrin III tetramethyl ester were obtained (Rimington, 1939). The melting point after one recrystallization was $136^{\circ} \mathrm{C}$. Vannotti (1954) gives the melting point of coproporphyrin III tetramethyl ester as $137^{\circ} \mathrm{C}$. There was too little of the coproporphyrin I isomer for crystallization.

The pigment ester from Band 3 was hydrolysed by dissolving it in concentrated $\mathrm{HCl}$ and allowing it to stand at room temperature overnight. The $\mathrm{HCl}$ was removed in a vacuum desiccator over solid $\mathrm{KOH}$, and the resultant pigment dissolved in a little 2:6-lutidine. The solution was spotted on to Whatman No. 4 paper with markers of chlorin- $\mathrm{e}_{6}$, coproporphyrin I, coproporphyrin III, and haematoporphyrin, and the chromatograms were run at $26^{\circ} \mathrm{C}$ in 2:6-lutidine/water in an atmosphere of ammonia (Fig. 4). The pigment gave only one spot which travelled further than those of the tetracarboxylic coproporphyrin III, and took up a position approximating to that given by chlorin- $\mathrm{e}_{6}$ which has three carboxyl groups. It will be noted that spots of the crude extract from Amphitrite heart-body also gave this spot, but in this case it did not 
travel quite as far as the tricarboxylic chlorin spot. This is most likely due to retardation by the other pigments travelling behind it. From these data it is permissible to conclude that the pigment from Band 3 is a tricarboxylic porphyrin. The free porphyrin has an $\mathrm{HCl}$ number of $0.5-\mathrm{I} \cdot 0$.

Band 4 gave a very indeterminate spot on an ascending lutidine chromatogram, about the 4-carboxyl level, the fluorescence of which was not particularly intense. It would, therefore, seem that this is in fact some unesterified coproporphyrin.

The pigments obtained from the heart-body tissue were, therefore, coproporphyrins I and III, coproporphyrin III being the main pigment present, and a tricarboxylic porphyrin.

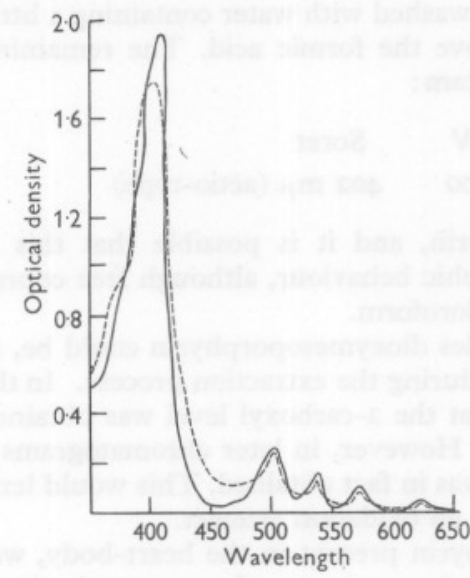

Fig. 6

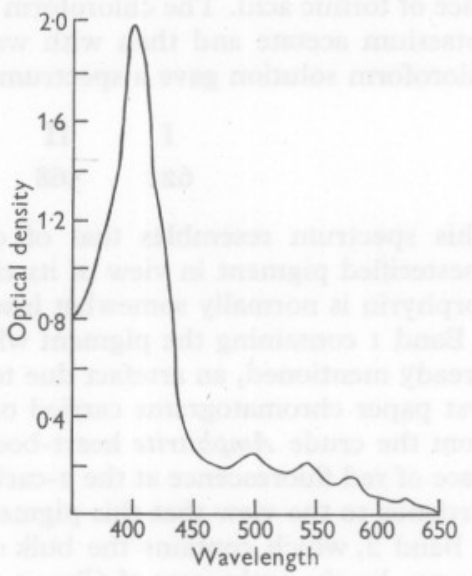

Fig. 7

Fig. 6. Absorption curves of main heart-body pigment ester (Band 2) in $\mathrm{CHCl}_{3}$ (broken line) and of coproporphyrin I tetramethyl ester in $\mathrm{CHCl}_{3}$ (continuous line).

Fig. 7. Absorption curve of tricarboxylic porphyrin ester (Band 3 ) in $\mathrm{CHCl}_{3}$.

\section{Remaining tissues}

The coelomic cells, pink and brown (see Dales, 1957); the blood, the body wall, and the gut were all examined by the methods which have already been described for the heart-body. These results are summarized in Table $\mathrm{I}$, from which it will be seen that with the exception of the gut all these tissues contain haematin, shown to be protohaematin by histochemical tests. This haematin, treated with hydrazine hydrate gave a spectrum, Hartridge:

$$
\begin{array}{cc}
\text { I } & \text { II } \\
555 & 530 \mathrm{~m} \mu
\end{array}
$$

The haematin from the blood was certainly formed from the haemoglobin in the course of extraction.

Coproporphyrin III was present in the coelomic cells and the body wall in relatively small amounts as compared with that in the heart-body, and was entirely absent from the blood. The tricarboxylic pigment did not occur in any of these tissues.

The body wall and the heart-body contained a bright yellow intensely greenfluorescent pigment resembling in behaviour the pigment found in Arenicola and in holothurians. It is intended to investigate this pigment later. 


\section{Terebella lapidaria}

Coproporphyrin III was the only porphyrin present, occurring only in the heartbody. Protohaematin was detected in the coelomic cells, and in extracts of the blood, in which case it was formed from haemoglobin.

\section{Lanice conchilega}

Coproporphyrin III was the only porphyrin detected, and occurred in the heartbody and the gut.

\section{Cirratulus cirratus}

Coproporphyrin III was detected in the heart-body together with protohaematin. Protohaematin was also detected in the body wall plus gut.

\section{Audouinia tentaculata}

The heart-body, the blood and the gut contained coproporphyrins I and III, with the III isomer predominating. Protohaematin was derived from the haemoglobin, in the blood extracts, and this pigment possibly occurred in the body wall. The heartbody and the gut also contained a colourless compound giving an intense blue fluorescence in u.v. light (c.f. Flabelligera).

\section{Melinna palmata}

Coproporphyrin III was detected in the heart-body, but not in the body wall or the gut. The heart-body in addition contained some of the yellow, green-fluorescent pigment found in Amphitrite.

\section{Flabelligera affinis}

The heart-body and the gut contained coproporphyrin III. Ether-acetic extracts of the heart-body and of the body wall when washed with water showed an intense bright blue fluorescence in u.v. light apparently masking or quenching that due to coproporphyrin. The residue was a dark green in colour, and was non-fluorescent. Chromatographed in the long paper apparatus in $2: 6$-lutidine/water at $23^{\circ} \mathrm{C}$ in an atmosphere of ammonia, an intensely blue-fluorescent spot was formed at $R_{F} 0.6$, which is at the 4-carboxyl level. Again, the fluorescence of the coproporphyrin seemed to be masked. On washing the ether-acetic acid extract with water, the bluefluorescent pigment became hypophasic and could thereby conveniently be separated. The ether epiphase when concentrated in vacuo gave the spectrum (Hartridge) of coproporphyrin, and when examined chromatographically, only the III isomer could be detected. The water hypophase containing the blue-fluorescent pigment was extracted with $n$-butanol, when all the pigment went into the butanol phase. Evaporated to dryness in vacuo and redissolved in butanol, no definite absorption spectrum was given in the spectrophotometer (Fig. 8). This pigment is interesting in that it is extremely soluble in both fat solvents and in water, and it has a definite $R_{F}$ value. Fox, Crane \& McConnaughey (1948) described non-carotenoid blue-fluorescent chromolipoids from Thoracophelia mucronata. These pigments have single sharp maxima in the u.v. at from 310 to $300 \mathrm{~m} \mu$ or below, but the pigment of Flabelligera does not seem to be of this type since it has no definite maxima, and is extremely soluble in water. It is possible that the pigment is related to fluorocyanine. Phaeophorbide- $a$ was also detected in the ether epiphase, and the dark green non-fluorescent residue from the ether extraction when treated with mineral acids gave the absorption 
spectrum of phaeophorbide- $a$. Copper was detected in the ash. The dark green nonfluorescent pigment in the residue must, therefore, be a copper phaeophorbide- $a$. This pigment has already been detected in the mollusc Akera bullata (Kennedy \& Vevers, 1956).

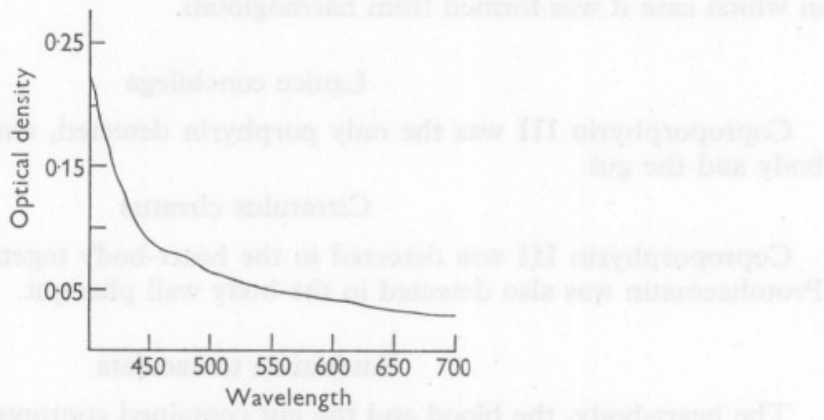

Fig. 8. Absorption curve of blue-fluorescent pigment from Flabelligera in $n$-butanol.

\section{Polycirrus caliendrum}

Coproporphyrin III was the only porphyrin detected, and occurred in extracts of the whole body, the body wall, and the gut. (Polycirrus is without vascular system, and hence heart-body.)

\section{Myxicola infundibulum}

Coproporphyrin III and chlorohaematin were found in the body wall plus gut, but not in the anterior nephridia. It is most likely that the haematin came from the bodywall tissue. Coproporphyrin III has been found previously in the gut (Kennedy \& Vevers, 1954), and chlorohaematin can be prepared from the blood (Kennedy, I953b).

\section{Arenicola marina}

Ashworth (1904) reports intravasal tissue increasing with age within the hearts of Arenicola. This was found in insufficient quantity for extraction. Extravascular tissue, also increasing with age, related to certain vessels from the hinder part of the intestine, occurs in larger amounts, and extracts were made of this tissue and of the body wall of pink and dark worms (Fig. 2).

Extravasal tissue was removed from a number of worms, homogenized, washed with sea water, and centrifuged. This process was repeated until the tissue was freed from blood. No absorption band was visible with the microspectroscope; the spectrum of oxyhaemoglobin was absent. After the addition of a drop of hydrazine hydrate, the pink colour of a haemochromogen appeared. This gave a two-banded spectrum in the microspectroscope at

$$
\begin{array}{ccc}
\text { I } & \text { II } & \\
555 & 525 \mathrm{~m} \mu & \text { (order of intensity I-II) }
\end{array}
$$

This is the spectrum given by protohaemochromogen, indicating that protohaem is present in the tissue, most probably as haematin. A drop of $2 \mathrm{~N}-\mathrm{HCl}$, added to a smear of the extravasal tissue on a slide, produced the spectrum of acid haematin with a strong maximum of $660 \mathrm{~m} \mu$. This is characteristic of acid protohaematin. The smear of the extravasal tissue allowed to dry on a slide shows very little, if any, fluorescence 
in u.v. light. A drop of ethanol, when added, caused the appearance almost immediately of a bright yellowish green fluorescence resembling that already described in Amphitrite and Melinna. This fluorescent pigment was washed off with ether, after which no fluorescence was apparent. A drop of formic acid produced a bright red fluorescence at once. Examined with the microspectroscope the absorption spectrum of coproporphyrin became apparent, with a slight shift of the bands towards the red due to formic acid. The non-appearance of coproporphyrin spectrum on examination of the fresh tissue may be due to the fact that the porphyrin is almost certainly present in combination with protein in the extravasal tissue. The addition of formic acid would not be sufficient to break down a haematin in the cold.

Fresh Arenicola blood gives a spectrum of oxyhaemoglobin:

$$
\begin{array}{ccc}
\text { I } & \text { II } & \\
578 & 540 \mathrm{~m} \mu & \text { (Hartridge) }
\end{array}
$$

The addition of a drop of hydrazine hydrate produced the haemochromogen:

$$
\begin{array}{ccc}
\text { I } & \text { II } & \\
555 & 525 \mathrm{~m} \mu & \text { (Hartridge) }
\end{array}
$$

and bubbling carbon monoxide through a sample of haemolysed blood produced a spectrum:

$$
\begin{array}{ccc}
\text { I } & \text { II } & \\
570 & 540 \mathrm{~m} \mu & \text { (Hartridge) }
\end{array}
$$

of carboxyhaemoglobin. These experiments were sufficient to indicate that the blood contains a haemoglobin with protohaem as its prosthetic group. A drop of fresh blood treated with dilute $\mathrm{HCl}$ produced a brown coagulum. This did not fluoresce with u.v. light, even after the addition of formic acid, and this is conclusive proof that the blood does not contain a free porphyrin.

These experiments indicate that the porphyrin in the extravasal tissue does in fact come from that tissue and not from the blood. The tissue also contains protohaematin.

Coproporphyrin I and coproporphyrin III, with the III isomer predominating, were found in the extravasal tissue and the body wall of light and dark animals. All these tissues also contained the tricarboxylic porphyrin already described from the heart-body of Amphitrite, and in addition they contained protohaematin. The body wall of both dark and light animals also produced the yellow, green-fluorescent pigment described in Amphitrite and Melinna. Such a pigment has been described by Lignac (1945) and van Duijn, Havinga \& Lignac (195I) in Arenicola and called arenicochrome. It may well be that it is this pigment which occurs in Amphitrite and Melinna. This will be the subject of a future investigation.

Ether-acetic acid extracts of the extravasal tissue and the body wall of dark and light animals were washed with water, concentrated and spotted on Whatman No. 4 filter paper with markers of coproporphyrin I and III, chlorin- $\mathrm{e}_{6}$, and haematoporphyrin, and chromatograms were run using the ascending method of Eriksen (1953) (Fig. 4). In each case spots of coproporphyrin I and coproporphyrin III were obtained, coproporphyrin III predominating, together with a spot at the tricarboxylic level. The ether extracts were evaporated to dryness and the pigment esterified by adding a mixture of methanol 19 parts: concentrated sulphuric acid I part, and allowing the solution to stand at room temperature for $48 \mathrm{~h}$. The esterified pigments were extracted by diluting with an equal volume of water and shaking with chloroform. After washing the chloroform extract with $2 \%$ sodium chloride followed by water, and drying the solution roughly by passing it through chloroform-soaked paper, the 
pigments were chromatographed on a column of $\mathrm{MgO}$, grade III (Nicholas, 195I). Apart from a dark brown band at the top of the column which did not move when the chromatogram was developed with the chloroform-methanol mixture as before, only one broad, pink, red-fluorescent band developed. When collected in chloroform this band gave an absorption spectrum (Hartridge):

$\begin{array}{cccc}\text { I } & \text { II } & \text { III } & \text { IV } \\ 622 \cdot 3 & 565 \cdot 5 & 533 & 501 \mathrm{~m} \mu\end{array}$

From the paper-chromatographic data and this spectrum, the pigment can be identified as coproporphyrin.

From the body wall of the dark animals a large amount of coproporphyrin isomers was isolated; much less, although still an appreciable quantity, could be extracted from the light (pink) animals. When crystallized as described for Amphitrite, the coproporphyrin III tetramethyl ester gave a melting point of $137.9^{\circ} \mathrm{C}$. The coproporphyrin I again was present in too small a quantity to be isolated.

From this work it may be seen that coproporphyrin III is the predominating pigment in the heart-bodies of all the species examined. The tricarboxylic porphyrin was only detected in Amphitrite and Arenicola extravasal tissue, but this could be because much larger amounts of these worms were available, and only a few specimens of some of the other species could be obtained.

\section{DISCUSSION}

The chief interest in this work is centred in the presence of relatively large amounts of coproporphyrin III, together with traces of coproporphyrin I, a tricarboxylic porphyrin, and haematin in the heart-body. The fact that all these pigments can be isolated from the heart-body tissue is very strong evidence in support of the view expressed by Meyer (I887) that the heartbody is an haematopoietic organ. A possible scheme for the biosynthesis of

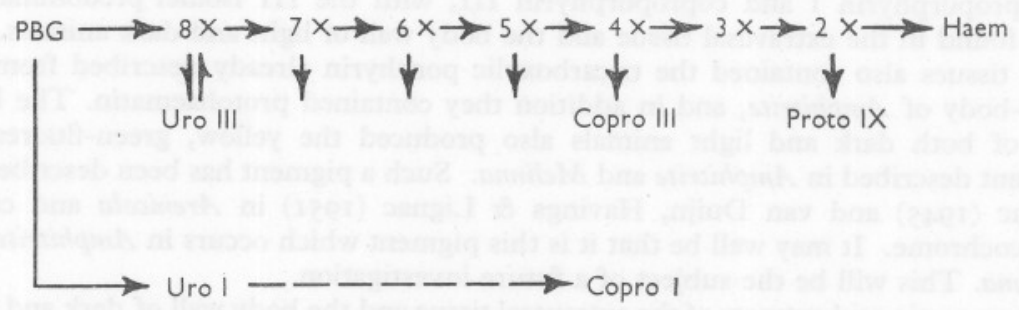

Fig. 9. A scheme for the biosynthesis of haem (Dresel, 1955).

haem is that of Dresel (1955) represented in Fig. 9. In this scheme porphobilinogen (PBG) is converted into an 8-carboxyl leuco-compound or prouroporphyrin III, which is then progressively decarboxylated each time to the III leuco-compound and finally dehydrogenated, with the incorporation of Fe leading to haem. Dresel (1955) considers that observations of porphyrins with from 8- to 2-carboxyl groups in many different biological situations lend support to such a scheme. If this system proceeds normally, only minute traces of free porphyrins are formed. However, in the porphyrias, where 
aberrations of the biosynthetic process occur, free porphyrins are formed, that is to say, the leuco-compounds are oxidized to the coloured free porphyrins which then find their way into the tissues. Once these free porphyrins have been formed they apparently cannot play any further part in the synthesis of the haem molecule. Eriksen (1955) put forward some evidence for the conversion of free uroporphyrin and coproporphyrin to protoporphyrin in the biosynthetic cycle, but this has not been supported, and has been criticized by Schwartz \& Ikeda (I955), by Shemin (1955) and by Dresel (1955). The metabolism of the series I porphyrins appears to follow a different pathway in which the free porphyrins, at any rate uroporphyrin I and coproporphyrin I, appear. Lockwood \& Rimington (I957) have succeeded in purifying an enzyme which converts PBG to uroporphyrin, and for which they propose the name porphobilinogenase (PBGase). This enzyme produces uroporphyrin III from PBG apparently without trace of uroporphyrin I. If, however, the enzyme is heated for $15 \mathrm{~min}$ at $55^{\circ} \mathrm{C}$, it produces from PBG at $37^{\circ} \mathrm{C}$, uroporphyrin I, with a trace of uroporphyrin III, and no ether-soluble porphyrin is formed by either the heated or unheated enzyme. PBGase was prepared from chicken erythrocytes, and Lockwood (private communication) has shown that with Conger-eel erythrocytes, addition of PBG after haemolysis and incubation at room temperature produces large amounts of coproporphyrin III and protoporphyrin IX, with practically no uroporphyrin.

In the porphyrias, where the free porphyrins are formed, these may be both series I and series III according to the type of syndrome. In congenital porphyria, which is a gene-controlled disturbance of the haematopoietic system, quantities of uroporphyrin I and coproporphyrin I are formed, and Rimington \& Booij (I957) found that a haemolysate prepared from the blood of a case of congenital porphyria produced considerable quantities of these porphyrins together with the series III isomers. Photosensitization occurs as well in congenital porphyria, and PBG is absent. In idiopathic porphyria, series III isomers predominate, and PBG is present. These findings give further support to Dresel's scheme (Fig. 9), and for the suggestion that series I isomers have a separate metabolic route. Booij \& Rimington (I957) suggest that because a haemolysate of congenital porphyria blood incubated with PBG at $37^{\circ} \mathrm{C}$ yields a mixture of series I and III porphyrins, 'the defect is present in some at least of the circulating cells and is not confined to processes occurring in the bone marrow during early maturation of the erythrocytes'. All these studies have an important bearing on the present problem of the function of the polychaete heart-body, and on the occurrence of porphyrins in marine invertebrates. It is possible that in the polychaetes with haemoglobin which we have examined, there exists a kind of idiopathic porphyria in which the haem biosynthesis system is inefficient. In such a system the intermediates in the chain of reactions in Fig. 9, namely, coproporphyrin III, coproporphyrin I, and the tricarboxylic porphyrin, have been 
deposited in the tissues in their oxidized form and their metabolism to haem cannot, consequently, be carried further. Kench, Langley \& Wilkinson (1953) found that extracts of stools of a porphyria patient, when chromatographed on paper, gave the whole gamut of porphyrins from 8-carboxyl down to 2-carboxyl. In molluscs, if free porphyrin is present it is uroporphyrin I which occurs (Kennedy \& Vevers, 1954; Kennedy, 1958). In molluscs which have a shell the porphyrin is laid down in the shell, very often in a definite pattern, and in those molluscs which are without shells or have very reduced shells, such as the tectibranchs and land slugs, if uroporphyrin I is present it occurs in the integument. The deposition of uroporphyrin in these molluscs seems to be closely connected with calcium metabolism, and indeed Turner (1937) associated the formation of uroporphyrin I which occurs in the bones of the Pennsylvanian fox-squirrel (Sciurus niger), with the megaloblasts of the bone marrow. It is significant that it is the black variety of the slug, Arion ater in which the greatest amount of uroporphyrin I occurs (Kennedy, 1958), the amount of porphyrin being closely parallel to the amount of melanin in the integument, so that in the very pale grey specimens, no uroporphyrin I is detectable. Sciurus niger has black hair, so that in these two widely differing animals an additional pigment is present, namely melanin, which protects these animals from the photosensitizing effects of the porphyrin. Aplysia and Akera which are more darkly coloured, have more uroporphyrin I than Duvaucelia which has a bright orange pigment; there was a much greater concentration of coproporphyrin III in the body wall of the dark coloured Arenicola and Amphitrite than in the lighter, pink specimens: the more darkly pigmented Asterias contained more protoporphyrin IX than the paler animals (Kennedy \& Vevers, 1953) although protoporphyrin is not noteworthy for its photosensitizing action. Fischer \& Zerweck (1924) have shown in mammals that photosensitivity to u.v. light increases with the number of carboxylic groups in the porphyrin molecule, the action of proto-, deutero- and mesoporphyrin is very slight, but copro- and uroporphyrin have an intense photosensitizing action. The exception to this is haematoporphyrin which has not been detected free in nature so far, which has the greatest photosensitizing effect of all, and which has two carboxyl groups and two hydroxyethyl groups.

\section{CONCLUSIONS}

These results suggest that the heart-bodies (when present) in polychaetes are haematopoietic tissues.

Types of porphyria comparable with those described in man occur in invertebrates, and this may explain the apparently random distribution of free porphyrins in marine animals. Further support is given to the view that porphyrin metabolism and calcium metabolism are closely associated. Since all animals in which photosensitizing porphyrins occur also have dark 
pigments (frequently melanin, and sometimes carotenoid) the latter presumably have a protective function.

The ability of the heart-body and other polychaete tissues to form porphyrins from added PBG and $\delta$-aminolaevulinic acid (ALA) will be the subject of a further investigation. It is of the first importance also to determine whether the heart-bodies contain PBGase. These experiments may lead to an understanding of the formation in the heart-bodies of the coproporphyrin III in such large amounts.

It is also of interest to note here that the suggestion of Picton (1898) that the heart-body is formed from an infolding of extravasal epithelia, is amply borne out by the equivalence, as shown by the porphyrins present, of the heart-bodies with the extravasal tissue in Arenicola, tissue frequently referred to by previous authors as 'chloragogen' (Romieu, I923). It thus seems possible that such extravasal 'chloragogen' in polychaetes fulfils an haematopoietic role, without excluding the possibility that it participates in excretion or food storage as well (Dales, 1957). Romieu (1923) regarded the results of his histochemical and histological investigations as providing evidence for regarding the heart-body as a 'storage kidney', or intravascular 'chloragogue'. It is also intended to investigate this further. Eisig (I887) considered that the brown or brown-green pigment of the heart-body in Terebella lapidaria was a derivative of haemoglobin. Romieu (1923) did not agree with this, and did not elicit the reactions for haematin or biliverdin; he was of the opinion that this brown pigment was a 'urochrome', and compared it with chaetopterin, which he said was a modified chlorophyll, the comparison resting solely on its solubility in acetic acid and on its colour. Kennedy \& Nicol (1958) have shown that the pigment hitherto known as chaetopterin is a mixture of phaeophorbides $a$ and $b$, and as such could in fact be regarded as a modified chlorophyll. Experiments described in this present paper confirm Eisig's view that the brown granules in the heart-body (and also in the extravasal tissue of Arenicola) are a derivative of haemoglobin, in fact, haematin.

\section{SUMMARY}

The heart-bodies and some other tissues of a number of polychaetes have been examined chemically, and the porphyrin pigments from these tissues described. Coproporphyrin III was shown to be present in relatively large concentration in all the heart-bodies, together with traces of coproporphyrin I, a tricarboxylic porphyrin and protohaematin. The body wall of light (pink) and dark (brown) coloured Arenicola and of Amphitrite also contained these pigments in varying amounts. Other non-porphyrin pigments were also seen in the body wall of some animals, the most remarkable being a colourless compound with a bright blue-fluorescence occurring in Flabelligera. Evidence is presented which supports the view that the heart-body is an haematopoietic 
organ, and the significance of this is discussed. Parallels are drawn between the occurrence of free porphyrins in marine animals and the occurrence of such pigments in porphyrias in man.

\section{REFERENCES}

Ashworth, J. H., 1904. Arenicola. L.M.B.C. Memoirs, No. II, II8 pp. London: Williams and Norgate.

BlOch-RAPHAEL, C., I939. Localisation, formation et destruction de l'hémoglobine chez les Annélides Polychétes. Ann. Inst. océanogr. Monaco, T. I9, Fasc. I, pp. $\mathrm{I}-78$.

Booij, H. L. \& Rimington, C., 1957. Effect of pre-heating on porphyrin synthesis by red cells. Biochem. F., Vol. 65, p. 4P.

ChU, J. C., Green, A. A. \& ChU, E. J., 195r. Microchromatography of porphyrin esters. F. biol. Chem., Vol. 190, pp. 643-6.

DALES, R. P., I957. Preliminary observations on the role of the coelomic cells in food storage and transport in certain polychaetes. F. mar. biol. Ass. U.K., Vol. 36, pp. 9I-IIO.

Dresel, E. I. B., I955. The biosynthesis of haem. Ciba Foundation Symposium on Porphyrin Synthesis and Metabolism. 308 pp. London: Churchill.

Eisig, H., I887. Monographie der Capitelliden des Golfes von Neapel. Fauna $u$. Flora Neapel, Monogr. 16, 906 pp. Berlin: Friedländer.

ERIKSEN, L., 1953. Paper chromatography of porphyrin pigments. Scand. F. clin. Lab. Invest., Vol. 5, pp. 155-7.

- 1955. The relation of free erythrocyte porphyrins to haemoglobin biosynthesis. Ciba Foundation Symposium on Porphyrin Synthesis and Metabolism. 308 pp. London: Churchill.

FAUVEL, P., I897. Recherches sur les Ampharétiens, Annélides Polychètes sédentaires. Bull. sci. Fr. Belg., T. 30, pp. 277-488.

FISCHER, H. \& ZERWECK, W., I924. Úber der Haemfarbstoff. Z. phys. Chem., Vol. I37, pp. 176.

Fox, D. L., Crane, S. C. \& McConnaughey, B. H., I948. A biochemical study of the marine annelid worm, Thoracophelia mucronata. f. mar. Res., Vol. 8, pp. $567-85$.

Kench, J. E., Langley, F. A. \& Wilkinson, J. F., I953. Biochemical and pathological studies on congenital porphyria. Quart. F. Med., Vol. 22, pp. 285-94.

KenNedy, G. Y., I953a. Partition paper chromatography of the porphyrins. Scand, F. clin. Lab. Invest., Vol. 5, pp. 281-4.

- $1953 \mathrm{~b}$. Chlorocruoroporphyrin: a simple method of preparation. F. mar. biol. Ass. U.K., Vol. 32, pp. 365-6.

Kennedy, G. Y. \& Vevers, H. G. 1953. The biology of Asterias rubens L. V. A porphyrin pigment in the integument. F.mar.biol. Ass. U.K., Vol. 32, pp. 235-47.

- 1954. The occurrence of porphyrins in certain marine invertebrates. f. mar. biol. Ass. U.K., Vol. 33, pp. 663-76.

1956. Porphyrin pigments in the tectibranch mollusc Akera bullata O. F. Müller. F. mar. biol. Ass. U.K., Vol. 35, pp. 35-9.

LigNAC, G. O. E., I945. About arenicochrome and its possible significance as a mesocatalyst. Proc. Acad. Sci. Amst., Vol. 48, pp. 406-ro.

Lockwood, W. H. \& Rimington, C., 1957. Purification of an enzyme converting porphobilinogen to uroporphyrin. Biochem. F., Vol. 67, p. 8P. 
MeYER, E., 1887. Studien über den Körperbau der Anneliden. Mitt. zool. Sta. Neapel, Bd. 7, pp. 592-741.

Nicholas, R. E. H., I95I. Chromatographic methods for the separation and identification of porphyrins. Biochem. F., Vol. 48, pp. 309-13.

Picton, L. J., I898. On the heart-body and coelomic fluid of certain Polychaeta. Quart. F. micr. Sci., Vol. 4I, pp. 263-302.

Rimington, C., I939. A reinvestigation of turacin, the copper porphyrin pigment of certain birds belonging to the Musophagidae. Proc. roy. Soc., B, Vol. 127, pp. 106-20.

Rimington, C. \& Booij, H. L., 1957. Porphyrin biosynthesis in human red cells. Biochem. F., Vol. 65, p. 3P.

RomIEU, M., I923. Recherches histophysiologiques sur le sang et le corps cardiaque des Annélides Polychètes. Thés. Fac. Sci. Univ. Paris, 336 pp., Paris: Doin.

Salensky, W., I884. Études sur le développement des Annélides. Part III, Pileolaria, Aricia et Terebella. Arch. biol., Liège, Vol. 4, pp. I43-264.

SCHNEIDER, G., I897. UUber die Segmentalorgane und den Herzkörper einiger Polychäten. Arb. d. Kaiserl. Naturf. Ges. St Petersburg, Vol. 27, pp. 135-7.

- 1899. Über Phagocytose und Excretion bei den Anneliden. Z. wiss. Zool., Bd. 66 , pp. $497-520$.

SCHWARTZ, S. \& IKEDA, K., I955. Studies of porphyrin synthesis and interconnexion. Ciba Foundation Symposium on Porphyrin Synthesis and Metabolism. 308 pp. London: Churchill.

Shemin, D., 1955. Discussion. Ciba Foundation Symposium on Porphyrin Synthesis and Metabolism. $308 \mathrm{pp}$. London: Churchill.

TURNER, W. J., I937. Studies on porphyria. I. Observations on the fox-squirrel, Sciurus niger. F. biol. Chem., Vol. I18, pp. 519-30.

van Duijn, P., Havinga, E. \& Lignac, G. O. E., I95I. Arenicochrome, a new pigment from Arenicola marina L. Experientia, Vol. 7, pp. 376-7.

Vannotti, A., 1954. Porphyrins. 533 pp. London: Hilger and Watts. 